\title{
Growth of Four Varieties of Barley (Hordeum vulgare L.) in Soils Contaminated with Heavy Metals and Their Effects on Some Physiological Traits
}

\author{
Águeda González*, M. Carmen Lobo \\ Instituto Madrileño de Investigación y Desarrollo Rural, Agrario y Alimentación, Madrid, Spain. \\ Email: ${ }^{*}$ agueda.gonzalez@madrid.org
}

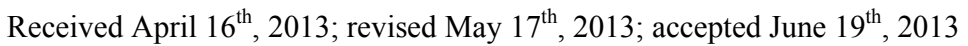

Copyright (C) 2013 Águeda González, M. Carmen Lobo. This is an open access article distributed under the Creative Commons Attribution License, which permits unrestricted use, distribution, and reproduction in any medium, provided the original work is properly cited.

\begin{abstract}
To evaluate the effect of zinc $(\mathrm{Zn})$, cadmium $(\mathrm{Cd})$, and chromium $(\mathrm{Cr})$ on growth and selected physiological traits in barley, a greenhouse trial was performed using four barley varieties that were exposed to different concentration of these metals. The parameters quantified were growth, chlorophyll content, and chlorophyll fluorescence during three phenological stages: flag leaf, anthesis, and grain filling. The metal concentrations in both the plant and soil were also quantified. We determined that the varieties studied were more tolerant to $\mathrm{Zn}$ and $\mathrm{Cd}$ than to $\mathrm{Cr}$. Treatment with $\mathrm{Zn}$ did not negatively affect growth, and only high concentrations of Cd decreased growth by approximately $4 \%$ to $8 \%$. Plants treated with the highest $\mathrm{Cr}$ concentration stopped growing at the flag leaf stage. The amount of metal that accumulated in the plant increased with increasing metal concentration, and the highest amount of accumulated metal was recorded in the root and shoot. Both the plant height and dry weight were higher in the CB502 variety plants, followed by the Reinette, Pedrezuela, and Plaisant varieties. The same trend was observed for the chlorophyll content and fluorescence, with a significant correlation between the growth parameters and chlorophyll content $(\mathrm{p}<0.001)$. Thus, we determined that barley has variability in the studied traits.
\end{abstract}

Keywords: Growth; Heavy Metal; Barley; Chlorophyll Content

\section{Introduction}

Environmental quality is increasingly affected by heavy metals present in the atmosphere, water, and soil. For this reason, the interest in understanding the toxic effects of heavy metals on crop growth and physiology has increased in the past few years.

All plants absorb heavy metals from the substrate in which they grow to different degrees. The metal concentrations in different parts of the plant depend on intrinsic (genetic) and extrinsic (environmental) factors and vary widely between the species and types of metal. Plants can tolerate large amounts of metal in their environment using two strategies: 1) Exclusion: The metal transport is restricted and minimal, and the metal concentration in the shoot remains relatively constant even within a wide range of metal concentrations in the soil. This is the most common strategy in species that are tolerant to metals; 2)

"Corresponding author.
Accumulation: Metals accumulate in a non-toxic form in the upper parts of terrestrial plants for both high and low concentrations present in the soil [1-3]. The ability of terrestrial plants to absorb contaminants from the rhizosphere and move them to the shoot has resulted in an increase in the number of studies on plants that can improve soils contaminated by heavy metals [4-7].

The use of crops for phytoremediation has the advantages of producing large amounts of biomass and a great adaptability to different environmental conditions. However, to be effective, the plants must be tolerant to contaminants and must also be capable of accumulating large amounts of toxic elements in their tissues [8]. If the concentration of contaminants in the crop biomass is below the critical level for cattle consumption, these crops can add important economic value to the extraction process. The phytoextraction of metals is a promising method that is applicable to soils that are mildly or moderately contaminated, and this is an alternative to ex-situ 
decontamination methods, which are both expensive and environmentally damaging $[2,3,9]$.

For phytoextraction, two groups of plants were considered: hyper-accumulating species that are capable of accumulating and tolerating high levels of metals, and species that produce large amounts of biomass, which compensates for their lower metal accumulation in tissues. In the latter group, cereal crops are increasingly of interest for phytoextraction processing of heavy metals [10-13]. Advances in plant improvement through genetic engineering, which can modify traits including absorption, transport, accumulation, and tolerance of metals, have opened new possibilities for phytoremediation $[7,14$, $15]$.

Hyper-accumulating plants are, by definition, hypertolerant to metals that accumulate in the shoot; however, some genetic studies suggest that accumulation and tolerance are independent traits [16]. In reality, accumulating plants must have both traits to potentially accumulate large amounts of metal [17]. A plant that is only capable of accumulating is unlikely to survive in environments with high levels of available metals.

Hyper-accumulating plants are much more efficient at translocating metals from the roots to the shoot than plants that are not hyper-accumulating. This can be explained by the lower sequestration of metals into root vacuoles, which is typical of non-accumulating plants, or by more efficient transport through the xylem [2].

Plant capacity for accumulating $\mathrm{Cd}, \mathrm{Cr}$, and $\mathrm{Zn}$ differs between genotypes $[12,18-20]$. The existence of variability, together with evidence that phytoextraction is a promising technique applicable to moderately contaminated soils and is an alternative to ex-situ decontamination, suggests that phytoremediation can offer a viable solution to metal-contaminated soils.

The goals of this study were as follows: 1) Evaluate the effect of different concentrations of $\mathrm{Zn}, \mathrm{Cd}$ and $\mathrm{Cr}$ on growth in four varieties of barley; 2) Study the relationship between growth and several physiological parameters; 3) Analyze the differences between the barley varieties studied.

\section{Materials and Methods}

\subsection{Plant Materials and Metal Treatments}

Four varieties of barley were used. These were two tworow varieties (Pedrezuela and Reinette) and two six-row varieties (CB502 and Plaisant). In November 2010, 156 pots of $4 \mathrm{~L}$ were planted in the greenhouse with two seeds per pot. The substrate used contained soil and sand in a 2:1 ratio. The pots were watered with tap water until the plants reached stage 20 using Zadoks' scale [21]. The pots were then divided into three groups of 34 pots each.
Each group was watered with solutions containing different concentrations of $\mathrm{Zn}, \mathrm{Cd}$, or $\mathrm{Cr}$ (VI). Four treatments were applied per group (T0, T1, T2, T3) with four pots per treatment. Control pots (T0) were watered with $400 \mathrm{ml}$ of tap water. The metal treated pots (T1 - T3) were watered up to the final crop cycle using $300 \mathrm{ml}$ of tap water $+100 \mathrm{ml}$ of the corresponding metal solution prepared using $\mathrm{ZnSO}_{4} \cdot 7 \mathrm{H}_{2} \mathrm{O}, \mathrm{CdCl}_{2} \cdot 2,5 \mathrm{H}_{2} \mathrm{O}$, or $\mathrm{K}_{2} \mathrm{Cr}_{2} \mathrm{O}_{7}$ for the $\mathrm{Zn}, \mathrm{Cd}$, and $\mathrm{Cr}$ treatments, respectively (Table $\mathbf{1}$ ).

\subsection{Plant Height and Dry Weight}

Plant height was measured at the beginning of the treatment (S0), which included the flag leaf stage (i.e., the S1 sampling stage (41 Zadoks)); at anthesis (i.e., S2 sampling stage (65 Zadoks)); and during grain filling (i.e., S3 stage (80 Zadoks)).

At the end of the crop cycle, spikes from each plant were removed and weighed. Next, the plants were cut at the soil level to collect the total biomass of the aerial part. The spikes were threshed in a spike thresher (Precision Machine Co. Inc.), and the grain obtained was ground using an IKA A10 grinder for metal analysis. Once washed, the roots from each plant were dried in a stove at $80^{\circ} \mathrm{C}$ for 48 hours to obtain the dry weight.

\subsection{Metal Analysis}

The metals in the stem and root were extracted after acid digestion of ashes. The soil metals were extracted in an acid medium using a microwave extraction system (Multiwave 3000, Anton Paar GmbH, Graz, Austria). The analysis of $\mathrm{Cd}, \mathrm{Zn}$, and $\mathrm{Cr}$ in the corresponding extracts was performed using Atomic Absorption Spectroscopy (Varian AA 240 FS, Varian, Palo Alto, CA).

\subsection{Chlorophyll Content}

The evaluation of the chlorophyll content was performed in intact leaves using a portable device (SPAD-502). The samplings were performed at the flag leaf (S1), anthesis (S2), and grain filling (S3) stages based on the flag leaf of the main stem from each plant. Four measurements were extracted per plant, and the mean value was deter-

Table 1. Metal concentration applied by treatment.

\begin{tabular}{cccc}
\hline & \multicolumn{3}{c}{ Concentration $(\mathrm{mM})$} \\
\hline Treatment & $\mathrm{Zn}$ & $\mathrm{Cd}$ & $\mathrm{Cr}(\mathrm{VI})$ \\
T0 & 0 & 0 & 0 \\
T1 & 50 & 10 & 1 \\
T2 & 150 & 20 & 2 \\
T3 & 250 & 40 & 3 \\
\hline
\end{tabular}


mined for each leaf.

\subsection{Chlorophyll Fluorescence Measurements}

Chlorophyll fluorescence was measured at the flag leaf (S1), anthesis (S2), and grain filling (S3) stages using an F MS2 fluorometer (Hansatech Instruments Ltd., England). Fluorescence parameters were measured in the central part of the flag leaf of the main stem from each plant after adaptation to the dark for 30 minutes.

\subsection{Statistical Analysis}

The data were analyzed using SAS for analysis of variance. The means between treatments were compared using a Duncan test or with LSD values.

\section{Results}

\subsection{Effects of Zn, Cd, and Cr on Growth}

\subsubsection{Plant Height}

At the beginning of each treatment, the plant heights were similar between each genotype, with a mean of 42 , 33, 32, and $28 \mathrm{~cm}$ for the CB502, Pedrezuela, Reinette, and Plaisant varieties, respectively (Figure 1).

Plants treated with solutions containing a variety of $\mathrm{Zn}$ and $\mathrm{Cd}$ concentrations continued to grow until the end of the grain filling period, with a significantly greater mean plant height during this period than plant height at the beginning of the treatments or at the flag leaf stage. The differences observed in plant height between the anthesis and grain filling stages were very small and were not significant in the four genotypes studied. The growth of the treated plants compared to the growth of the control plants demonstrated the greatest difference in plants treated with the highest metal concentrations, which corresponded to treatment T3. In CB502 and Pedrezuela barley, the growth of the control plants was $45 \%$ and $50 \%$ respectively, similar to that of the plants treated with the highest $\mathrm{Zn}$ concentration. However, in plants treated with the highest $\mathrm{Cd}$ concentration, the growth was $41 \%$ for CB502 and $45 \%$ for Pedrezuela relative to the control plants. For the Reinette and Plaisant varieties, the mean growth of the control plants was $62 \%$. In plants treated with the highest concentration of $\mathrm{Zn}$, the growth was $58 \%$ for the two varieties. When the highest Cd concentration was used, the growth was $54 \%$ for Reinette and $56 \%$ for Plaisant.

Treatment with $\mathrm{Cr}$ affected plant growth more drastically in all genotypes studied. The mean height of the four barley varieties treated with $\mathrm{Cr}$ was significantly lower than the height of plants treated with different concentrations of $\mathrm{Zn}$ or Cd. As observed in Figure 1, only plants treated with the lowest concentrations of $\mathrm{Cr}$ con- tinued to grow until the end of the cycle. The growth of plants treated with the lowest $\mathrm{Cr}$ concentration was $27 \%$ for CB502, Pedrezuela, and Reinette, and 32\% for Plaisant. For the four varieties, the growth was lower than during treatments with the highest concentrations of $\mathrm{Zn}$ and $\mathrm{Cd}$. The growth of plants treated with the intermediate $\mathrm{Cr}$ concentration was $17 \%$ for Reinette and Pedrezuela and 7\% for Plaisant and CB502. The growth was $0 \%$ for plants treated with the highest $\mathrm{Cr}$ concentration for all four of the varieties studied.

\subsubsection{Dry Weight}

The mean dry weight for the aerial plant parts was greatest for CB502, followed by Reinette, Plaisant, and Pedrezuela. The differences between all four genotypes were statistically significant (Figure 2A). The dry weights of plants treated with $\mathrm{Zn}$ or $\mathrm{Cd}$ were similar and significantly higher than the weights of plants treated with $\mathrm{Cr}$. In plants treated with different concentrations of $\mathrm{Zn}$ and $\mathrm{Cd}$, the dry weight of control plants were very similar or even lower than the weights of the plants treated with the highest metal concentrations. Indeed, for Plaisant, the weights of the plants treated with the highest concentration of $\mathrm{Zn}$ and $\mathrm{Cd}$ were $86 \mathrm{~g}$ and $109 \mathrm{~g}$, respectively, and the weight of the control plants was $65 \mathrm{~g}$.

These results are expected because plants treated with $\mathrm{Zn}$ and $\mathrm{Cd}$ did not show toxicity symptoms such as leaf chlorosis until the end of the crop cycle. The leaves on plants treated with the highest concentrations of $\mathrm{Cd}$ dried earlier relative to the control; however, plants treated with $\mathrm{Cr}$ displayed the toxic effects produced by the metal across all treatments. Plants that demonstrated the most severe effect on growth were those treated with the highest concentration of $\mathrm{Cr}$. Indeed, these plants dried before completing the crop cycle. For all varieties studied, the dry weight of the plants treated with the highest $\mathrm{Cr}$ concentration was lower than the weight of the controls. The percent decrease with respect to the control plants was $88 \%, 87 \%, 86 \%$, and $79 \%$ for CB502, Pedrezuela, Reinette, and Plaisant, respectively.

The dry weights of the roots were higher in plants treated with $\mathrm{Zn}$ and $\mathrm{Cd}$. The dry weight varied between $12 \%$ in Reinette treated with $\mathrm{Zn}$ and $53 \%$ in Plaisant treated with the highest concentration of Cd (Figure 2B). The opposite occurred in plants treated with Cr. The reduction in root dry weight was recorded in all cases and was $61 \%, 77 \%, 36 \%$, and $40 \%$ for CB502, Pedrezuela, Reinette, and Plaisant, respectively.

The correlation of the dry weight of the aerial parts and roots was highly significant $(\mathrm{r}=0.68 ; \mathrm{p}<0.001)$. The correlations were also significant between the height and dry weight of the aerial parts $(\mathrm{r}=0.85 ; \mathrm{p}<0.001)$ and between the height and dry weight of the roots $(r=$ 

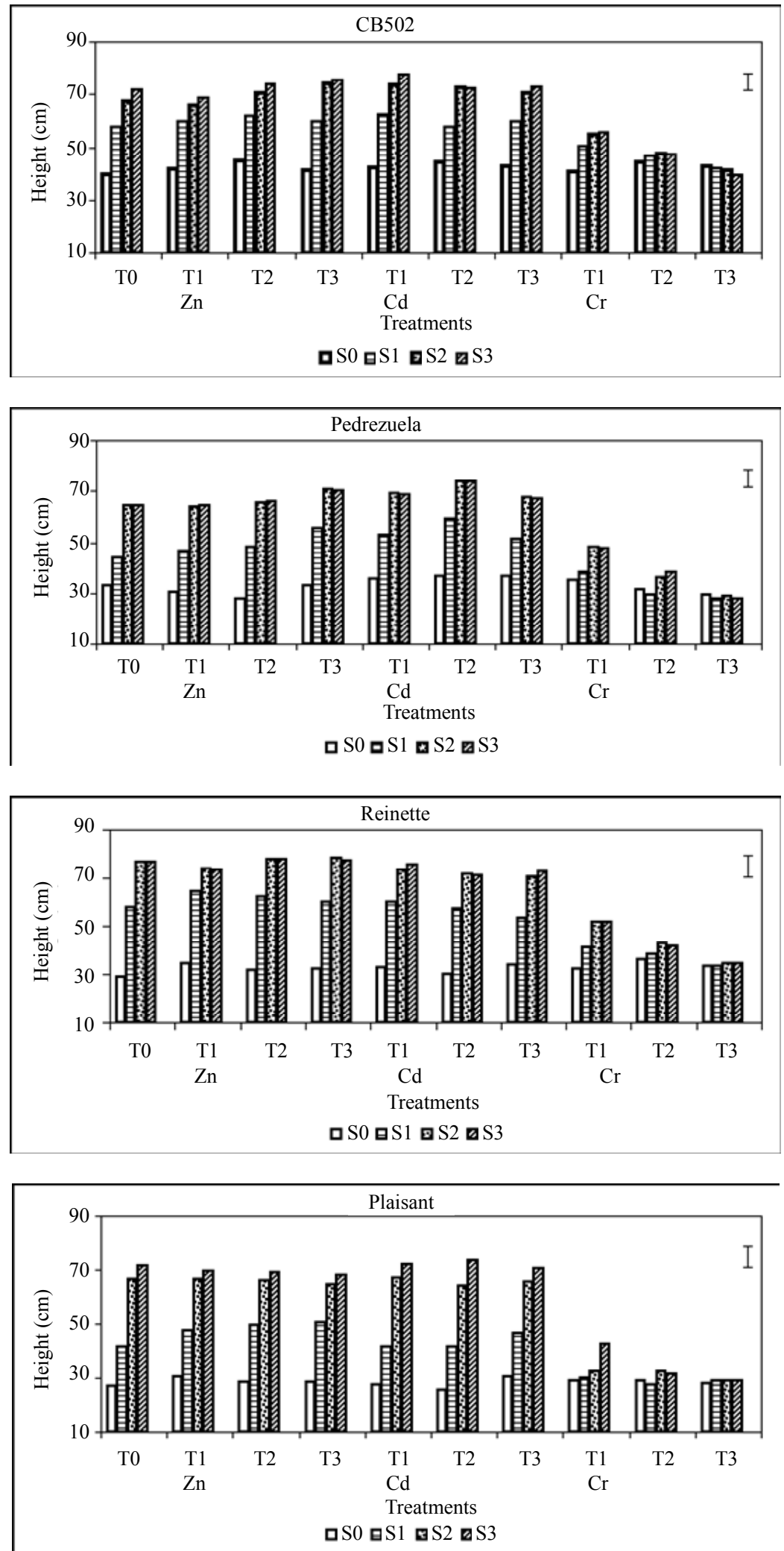

Figure 1. Heiht of the plants of four barley varieties at the beginning of treatment (S0) with different concentrations of Zn, $\mathrm{Cd}$ and $\mathrm{Cr}$ and sampling in flag leaf (S1), anthesis (S2) and grain-filling period (S3). Vertical bar represents the LSD value at $\mathrm{p}<\mathbf{0 . 5}$ for metalxtreatment interaction. 

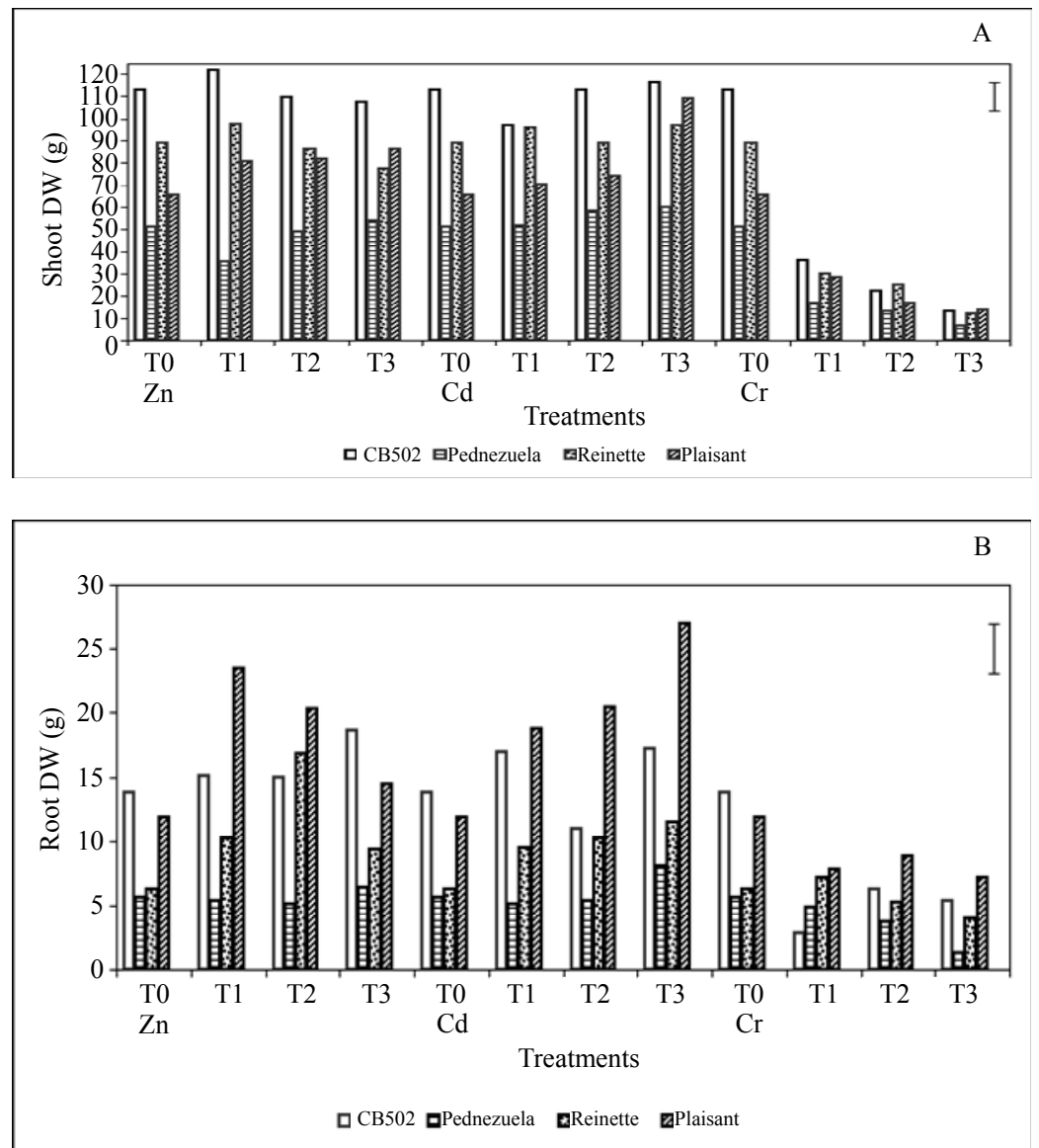

Figure 2. Effect of different treatments of Zn, $\mathrm{Cd}$ and $\mathrm{Cr}$ on dry weigts of shoot and roots of four barley varieties. Vertical bar represents the LSD value at $p<0.5$ for metalxtreatment interaction.

$0.43 ; \mathrm{p}<0.01)$.

\subsection{Metal Content in Plants}

For the Zn (Table 2) and Cd (Table 3) treatments, in all genotypes studied, the amount of metal accumulated in the plant increased with increasing metal concentration applied to the soil. In the Cr treatment (Table 4), significant differences exist only between the control and treatments. The correlation obtained between the metal accumulated in the plants and the concentration of metal applied to the soil was significant for both $\mathrm{Zn}$ and $\mathrm{Cr}(\mathrm{p}<$ $0.05)$ and $\mathrm{Cd}(\mathrm{p}=0.01)$.

In some genotypes, such as CB502 and Pedrezuela, the amount of accumulated $\mathrm{Cr}$ in the plants treated with the highest metal concentration was lower than that in the plants treated with lowest concentrations. This might be because the precocity of these two genotypes, as plants treated with higher concentrations dried earlier and therefore, stopped accumulating metal.

Significant differences in $\mathrm{Zn}$ and $\mathrm{Cd}$ accumulation in different plant parts existed, with higher amounts of metal accumulated in the root, followed by the shoot and then the grain, which contained a much lower concentration of accumulated metal in all genotypes studied (Tables 2 and 3). There were also differences in the amount of metal accumulated in the different genotypes studied. Based on the mean values, the Zn-treated Plaisant plants accumulated the highest concentration of metal (2698 $\mu \mathrm{g} / \mathrm{g})$, followed by Reinette $(1852 \mu \mathrm{g} / \mathrm{g})$ and CB502 (1464 $\mu \mathrm{g} / \mathrm{g})$. Pedrezuela variety plants accumulated the lowest amount of $\mathrm{Zn}(254 \mu \mathrm{g} / \mathrm{g})$. In the Cd treatments, Reinette accumulated the greatest amount of metal $(958 \mu \mathrm{g} / \mathrm{g})$, followed by Plaisant $(832 \mu \mathrm{g} / \mathrm{g})$ and CB502 $(707 \mu \mathrm{g} / \mathrm{g})$. The Pedrezuela variety plants accumulated the lowest amount of Cd $(405 \mu \mathrm{g} / \mathrm{g})$.

In the $\mathrm{Cr}$ treatment, the metal content in the grains was not analyzed because, due to Cr's high toxicity in plants, the higher concentration treatments dried out before grain filling.

In Pedrezuela, there were no significant differences between the amount of metal accumulated in the shoot and the roots (Table 4). In CB502, Reinette, and Plaisant, the amount of metal accumulated in the roots was sig- 
Table 2. Concentration of $\mathrm{Zn}$ in grain, shoots, roots and soil of four barley varieties treated with different concentrations of this metal.

\begin{tabular}{|c|c|c|c|c|c|c|}
\hline \multirow[b]{2}{*}{ Variety } & \multicolumn{2}{|l|}{$\mathrm{mM}$} & \multicolumn{3}{|c|}{$\mathrm{mg} / \mathrm{Kg} \mathrm{DW}$} & \multirow[b]{2}{*}{ Mean $^{*}$} \\
\hline & Treatment & Grain & Stems & Root & Soil & \\
\hline \multirow[t]{5}{*}{ CB502 } & 0 & 30.60 & 21.37 & 36.94 & 386 & $118.72 \mathrm{~d}$ \\
\hline & 50 & 62.10 & 655.68 & 1053.38 & 2437 & $1052.04 \mathrm{c}$ \\
\hline & 150 & 86.57 & 1766.06 & 4586.00 & 6233 & $3167.90 \mathrm{~b}$ \\
\hline & 250 & 93.99 & 3666.52 & 5514.90 & 8314 & $4397.35 \mathrm{a}$ \\
\hline & Mean $^{* *}$ & $68.31 \mathrm{~d}$ & $1527.40 \mathrm{c}$ & $2797.80 \mathrm{~b}$ & $4342.5 \mathrm{a}$ & \\
\hline \multirow[t]{5}{*}{ Pedrezuela } & 0 & 27.64 & 179.4 & 56.23 & 110.2 & $93.36 \mathrm{~b}$ \\
\hline & 50 & 91.46 & 196.2 & 330 & 485.8 & $275.86 \mathrm{ab}$ \\
\hline & 150 & 94.06 & 156.5 & 681 & 896 & $456.89 \mathrm{a}$ \\
\hline & 250 & 94.63 & 282.25 & 863 & 1758 & $749.47 \mathrm{a}$ \\
\hline & Mean $^{* *}$ & $76.94 \mathrm{a}$ & $203.58 \mathrm{a}$ & $482.55 \mathrm{a}$ & $812.5 \mathrm{a}$ & \\
\hline \multirow[t]{5}{*}{ Reinette } & 0 & 25.6 & 17 & 39 & 11.84 & $23.36 \mathrm{c}$ \\
\hline & 50 & 36.4 & 931 & 3165 & 519.7 & $1163.025 \mathrm{~b}$ \\
\hline & 150 & 27.25 & 153 & 8222 & 1016 & $2354.56 \mathrm{a}$ \\
\hline & 250 & 21.75 & 175 & 9898 & 1896 & $2997.68 \mathrm{a}$ \\
\hline & Mean $^{* *}$ & $27.75 \mathrm{~d}$ & $319 c$ & $5331 \mathrm{a}$ & $860.885 \mathrm{~b}$ & \\
\hline \multirow[t]{5}{*}{ Plaisant } & 0 & 31.50 & 32.08 & 250.73 & 41 & $88.82 \mathrm{c}$ \\
\hline & 50 & 79.45 & 1561.47 & 4438.68 & 1550 & $1907.40 \mathrm{~b}$ \\
\hline & 150 & 92.10 & 5275.24 & 9219.09 & 5732 & $5079.60 \mathrm{a}$ \\
\hline & 250 & 90.34 & 5352.70 & 5951.72 & 9087 & $5120.43 \mathrm{a}$ \\
\hline & Mean $^{* *}$ & $73.34 \mathrm{~b}$ & $3055.37 \mathrm{a}$ & $4965.05 \mathrm{a}$ & $4102.5 \mathrm{a}$ & \\
\hline
\end{tabular}

"Treatments followed by the same letter do not differ significantly $(\mathrm{p}<0.5)$ Duncan test; ${ }^{* *}$ Parts folloved by the same letter do not differ significantly $(\mathrm{p}<0.5)$ Duncan test.

Table 3. Concentration of $\mathrm{Cd}$ in grain, shoots, roots and soil of four barley varieties treated with different concentrations of this metal.

\begin{tabular}{|c|c|c|c|c|c|c|}
\hline & $\mathrm{mM}$ & & & $\mathrm{mg} / \mathrm{Kg}$ & & \\
\hline Variety & Treatment & Grain & Stems & Root & Soil & Mean $^{*}$ \\
\hline \multirow[t]{5}{*}{ CB502 } & 0 & 0.02 & 2.51 & 35.50 & 0.1 & $9.53 \mathrm{c}$ \\
\hline & 10 & 5.17 & 616.12 & 1951.64 & 679 & $812.98 \mathrm{~b}$ \\
\hline & 20 & 9.30 & 1181.51 & 411.24 & 1368 & $742.51 \mathrm{~b}$ \\
\hline & 40 & 17.73 & 1820.63 & 2429.48 & 2700 & $1741.96 \mathrm{a}$ \\
\hline & Mean $^{* *}$ & $8.05 \mathrm{~b}$ & $905.19 \mathrm{a}$ & $1206.96 \mathrm{a}$ & $1186.77 \mathrm{a}$ & \\
\hline \multirow[t]{5}{*}{ Pedrezuela } & 0 & 0.60 & 1.4 & 16.90 & 8 & $6.72 \mathrm{c}$ \\
\hline & 10 & 2.65 & 300 & 935 & 2596 & $958.41 \mathrm{~b}$ \\
\hline & 20 & 3.05 & 435 & 856 & 2580 & $968.51 \mathrm{~b}$ \\
\hline & 40 & 10.3 & 950 & 1349 & 5128 & $1859.32 \mathrm{a}$ \\
\hline & Mean $^{* *}$ & $4.15 \mathrm{c}$ & $421.6 \mathrm{~b}$ & $789.22 \mathrm{~b}$ & $2578 \mathrm{a}$ & \\
\hline \multirow[t]{5}{*}{ Reinette } & 0 & 0.02 & 1 & 2 & 5.6 & $2.15 \mathrm{~d}$ \\
\hline & 10 & 0.056 & 78 & 1623 & 1500 & $800.26 \mathrm{c}$ \\
\hline & 20 & 0.078 & 85 & 2287 & 2844 & $1304.02 \mathrm{~b}$ \\
\hline & 40 & 0.279 & 165 & 7251 & 5244 & $3165.07 \mathrm{a}$ \\
\hline & Mean $^{* *}$ & $0.11 \mathrm{~b}$ & $82.25 \mathrm{~b}$ & $2790.75 \mathrm{a}$ & $2398.4 \mathrm{a}$ & \\
\hline \multirow[t]{5}{*}{ Plaisant } & 0 & 1.04 & 6.13 & 6.41 & 0.1 & $3.41 \mathrm{c}$ \\
\hline & 10 & 5.25 & 327.93 & 986.23 & 732 & $512.85 \mathrm{~b}$ \\
\hline & 20 & 9.86 & 757.20 & 1058.24 & 627 & $613.07 \mathrm{~b}$ \\
\hline & 40 & 33.15 & 2008.19 & 4794.90 & 1455 & $2072.81 \mathrm{a}$ \\
\hline & Mean $^{* *}$ & $12.32 \mathrm{c}$ & $774.86 \mathrm{~b}$ & $1711.44 \mathrm{a}$ & $703.525 \mathrm{~b}$ & \\
\hline
\end{tabular}

*Treatments followed by the same letter do not differ significantly $(\mathrm{p}<0.5)$ Duncan test; ${ }^{* *}$ Parts followed by the same letter do not differ significantly $(\mathrm{p}<0.5)$ Duncan test. 
Table 4. Concentration of $\mathrm{Cr}$ in shoots, roots and soil of four barley varieties treated with different concentrations of this metal.

\begin{tabular}{|c|c|c|c|c|c|}
\hline \multirow[b]{2}{*}{ Variety } & \multirow{2}{*}{$\begin{array}{c}\mathrm{mM} \\
\text { Treatment }\end{array}$} & \multicolumn{4}{|c|}{$\mathrm{mg} / \mathrm{Kg} \mathrm{DW}$} \\
\hline & & Stems & Root & Soil & Mean $^{*}$ \\
\hline \multirow[t]{5}{*}{ CB502 } & 0 & 18.02 & 71.41 & 1.1 & $30.18 \mathrm{~b}$ \\
\hline & 1 & 684.01 & 3998.23 & 72 & $1584.74 \mathrm{a}$ \\
\hline & 2 & 1373.73 & 4670.80 & 57 & $2033.84 \mathrm{a}$ \\
\hline & 3 & 2244.95 & 3499.70 & 52 & $1932.22 \mathrm{a}$ \\
\hline & Mean $^{* *}$ & $1080.17 \mathrm{~b}$ & $3060.03 \mathrm{a}$ & $45.52 \mathrm{c}$ & \\
\hline \multirow[t]{5}{*}{ Pedrezuela } & 0 & 4.70 & 10.00 & 49.2 & $21.3 \mathrm{a}$ \\
\hline & 1 & 96 & 110 & 79.2 & $95.07 \mathrm{a}$ \\
\hline & 2 & 47.5 & 255 & 121.6 & $141.37 \mathrm{a}$ \\
\hline & 3 & 57.5 & 40 & 108.8 & $68.77 \mathrm{a}$ \\
\hline & Mean $^{* *}$ & $51.42 \mathrm{a}$ & $103.75 \mathrm{a}$ & $89.7 \mathrm{a}$ & \\
\hline \multirow[t]{5}{*}{ Reinette } & 0 & 6 & 42.1 & 58.4 & $35.5 \mathrm{c}$ \\
\hline & 1 & 320 & 3098 & 76.8 & $1164.93 \mathrm{~b}$ \\
\hline & 2 & 362 & 3837 & 39.6 & $1412.87 \mathrm{~b}$ \\
\hline & 3 & 364 & 5310 & 125.6 & $1933.2 \mathrm{a}$ \\
\hline & Mean $^{* *}$ & $263 \mathrm{~b}$ & $3071.77 \mathrm{a}$ & $75.1 \mathrm{~b}$ & \\
\hline \multirow[t]{5}{*}{ Plaisant } & 0 & 8.84 & 34.48 & 0.8 & $14.71 \mathrm{c}$ \\
\hline & 1 & 516.44 & 3388.00 & 93 & $1332.48 \mathrm{~b}$ \\
\hline & 2 & 1132.20 & 3653.15 & 106 & $1630.45 \mathrm{ab}$ \\
\hline & 3 & 1415.45 & 4692.69 & 37 & $2048.38 \mathrm{a}$ \\
\hline & Mean $^{* *}$ & $768.23 \mathrm{~b}$ & $2942.08 \mathrm{a}$ & $59.2 \mathrm{c}$ & \\
\hline
\end{tabular}

*Treatments followed by the same letter do not differ significantly $(\mathrm{p}<0.5)$ Duncan test; ${ }^{* *}$ Parts followed by the same letter do not differ significantly $(\mathrm{p}<0.5)$ Duncan test.

nificantly higher than that accumulated in the aerial parts of the plant.

CB502 accumulated the greatest amount of $\mathrm{Cr}(2070$ $\mu \mathrm{g} / \mathrm{g}$ ) based on the mean values per genotype, followed by Plaisant and Reinette (1855 and $1667 \mu \mathrm{g} / \mathrm{g}$, respectively). Pedrezuela accumulated the lowest amount of $\mathrm{Cr}$ $(78 \mu \mathrm{g} / \mathrm{g})$.

The amount of metal that remained in the soil was greatest for the higher concentration $\mathrm{Zn}$ and $\mathrm{Cd}$ treatments. The amounts measured in the soil were similar to those accumulated by the plants in the roots or in the shoot. However, in the Cr-treated plants, less metal remained in the soil; this result was different for the different treatments and genotypes, an effect likely due to the higher toxicity of $\mathrm{Cr}$ in plants.

\subsection{Chlorophyll Content}

The chlorophyll content in plants treated with different $\mathrm{Zn}$ concentrations was higher during the flag leaf and anthesis stages compared to the last sampling period, which was performed at the end of the grain filling period (Table 5). In the latter sampling period, the measurements were significantly lower in the four varieties studied. The differences between the control and the higher concentration treatments were small, with the highest measurements being those obtained in plants treated with the highest metal concentration, except for the Reinette variety, where the measurements did not differ from the control measurements.

Based on the mean values, the varieties can be separated into two groups. CB502 and Reinette had similar mean chlorophyll contents (45.89 and 45.35, respectively), which were significantly higher than the values obtained for Plaisant and Pedrezuela (41.99 and 35.40, respectively).

In the Cd treatments (Table 6), we observed the same trend found in the $\mathrm{Zn}$ treatments. The chlorophyll content measured in the last sampling period (S3) was significantly lower than those measured for the previous sampling periods (S1 and S2). For the four varieties studied, the chlorophyll content was higher in plants treated with increasing $\mathrm{Cd}$ concentrations than in the control plants. The varieties with the highest mean chlorophyll content were Reinette and CB502 (46.35 and 45.46, respectively), followed by Plaisant (43.39) and Pedrezuela (37.21).

Different results were observed for the $\mathrm{Cr}$ treatments (Table 7). First, we only recorded measurements for the first two sampling periods because the plants had dried out by the third period. The values for chlorophyll con- 
Table 5. Effect of different treatment of Zn on chlorophyll content of four barley varieties.

\begin{tabular}{|c|c|c|c|c|c|}
\hline \multirow[t]{2}{*}{ Variety } & \multirow{2}{*}{$\frac{\text { Treatment }}{\mathrm{mM}}$} & \multicolumn{3}{|c|}{ SPAD values } & \multirow[t]{2}{*}{ Mean $^{*}$} \\
\hline & & $S 1$ & $S 2$ & $S 3$ & \\
\hline \multirow[t]{5}{*}{ CB502 } & 0 & 45.32 & 45.32 & 35.50 & $42.05 \mathrm{c}$ \\
\hline & 50 & 46.95 & 50.30 & 37.88 & $45.04 \mathrm{~b}$ \\
\hline & 150 & 49.43 & 51.58 & 45.35 & $48.79 \mathrm{a}$ \\
\hline & 250 & 47.60 & 51.38 & 44.08 & $47.69 \mathrm{a}$ \\
\hline & Mean $^{* *}$ & $47.33 \mathrm{~b}$ & $49.65 \mathrm{a}$ & $40.70 \mathrm{c}$ & \\
\hline \multirow[t]{5}{*}{ Pedrezuela } & 0 & 44.32 & 40.85 & 15.78 & $33.65 \mathrm{~b}$ \\
\hline & 50 & 48.72 & 45.93 & 7.93 & $34.19 \mathrm{ab}$ \\
\hline & 150 & 48.25 & 46.07 & 14.67 & $36.33 \mathrm{a}$ \\
\hline & 250 & 50.66 & 48.10 & 13.49 & $37.41 \mathrm{a}$ \\
\hline & Mean $^{* *}$ & $47.98 \mathrm{a}$ & $45.24 \mathrm{~b}$ & $12.97 \mathrm{c}$ & \\
\hline \multirow[t]{5}{*}{ Reinette } & 0 & 46.70 & 45.31 & 37.70 & $43.24 \mathrm{c}$ \\
\hline & 50 & 49.93 & 52.63 & 45.22 & $49.26 \mathrm{a}$ \\
\hline & 150 & 48.00 & 48.89 & 40.81 & $45.9 \mathrm{~b}$ \\
\hline & 250 & 45.42 & 45.66 & 37.92 & $43 \mathrm{c}$ \\
\hline & Mean $^{* *}$ & $47.51 \mathrm{a}$ & $48.12 \mathrm{a}$ & $40.41 \mathrm{~b}$ & \\
\hline \multirow[t]{5}{*}{ Plaisant } & 0 & 40.64 & 42.68 & 40.28 & $41.2 \mathrm{ab}$ \\
\hline & 50 & 44.42 & 43.88 & 40.57 & $42.95 \mathrm{a}$ \\
\hline & 150 & 41.04 & 41.01 & 35.97 & $39.34 \mathrm{~b}$ \\
\hline & 250 & 44.63 & 45.81 & 42.93 & $44.46 \mathrm{a}$ \\
\hline & Mean $^{* *}$ & $42.69 \mathrm{a}$ & $43.34 \mathrm{a}$ & $39.94 \mathrm{~b}$ & \\
\hline
\end{tabular}

*Treatments followed by the same letter do not differ significantly $(\mathrm{p}<0.5)$ Duncan test; ${ }^{* *}$ Sampling followed by the same letter do not differ significantly $(\mathrm{p}<0.5)$ Duncan test.

Table 6. Effect of different treatments of Cd on chlorophyll content of four barley varieties.

\begin{tabular}{|c|c|c|c|c|c|}
\hline \multirow[t]{2}{*}{ Variety } & \multirow{2}{*}{$\frac{\text { Treatment }}{\mathrm{mM}}$} & \multicolumn{3}{|c|}{ SPAD values } & \multirow[t]{2}{*}{ Mean $^{*}$} \\
\hline & & $S 1$ & $S 2$ & S3 & \\
\hline \multirow[t]{5}{*}{ CB502 } & 0 & 45.32 & 45.32 & 35.50 & $42.05 \mathrm{~b}$ \\
\hline & 10 & 49.77 & 51.23 & 37.15 & $46.05 \mathrm{a}$ \\
\hline & 20 & 46.88 & 51.32 & 39.15 & $45.78 \mathrm{a}$ \\
\hline & 40 & 51.25 & 52.47 & 40.15 & $47.95 \mathrm{a}$ \\
\hline & Mean $^{* *}$ & $48.31 \mathrm{a}$ & $50.08 \mathrm{a}$ & $38.24 \mathrm{~b}$ & \\
\hline \multirow[t]{5}{*}{ Pedrezuela } & 0 & 44.32 & 40.85 & 15.78 & $33.65 \mathrm{c}$ \\
\hline & 10 & 49.82 & 47.92 & 13.87 & $37.2 \mathrm{~b}$ \\
\hline & 20 & 49.52 & 46.84 & 17.44 & $37.93 \mathrm{~b}$ \\
\hline & 40 & 52.17 & 49.51 & 18.47 & $40.05 \mathrm{a}$ \\
\hline & Mean $^{* *}$ & $48.95 \mathrm{a}$ & $46.28 \mathrm{~b}$ & $16.39 \mathrm{c}$ & \\
\hline \multirow[t]{5}{*}{ Reinette } & 0 & 46.70 & 45.31 & 37.70 & $43.24 \mathrm{c}$ \\
\hline & 10 & 47.90 & 50.51 & 43.86 & $47.42 \mathrm{ab}$ \\
\hline & 20 & 46.33 & 49.61 & 41.86 & $45.93 \mathrm{~b}$ \\
\hline & 40 & 49.56 & 51.21 & 45.66 & $48.81 \mathrm{a}$ \\
\hline & Mean $^{* *}$ & $47.62 \mathrm{a}$ & $49.16 \mathrm{a}$ & $42.27 \mathrm{~b}$ & \\
\hline \multirow[t]{5}{*}{ Plaisant } & 0 & 40.64 & 42.68 & 40.28 & $41.2 \mathrm{~b}$ \\
\hline & 10 & 41.52 & 44.78 & 42.37 & $42.89 \mathrm{~b}$ \\
\hline & 20 & 45.68 & 46.90 & 44.08 & $45.55 \mathrm{a}$ \\
\hline & 40 & 44.31 & 47.26 & 40.19 & $43.92 \mathrm{a}$ \\
\hline & Mean $^{* *}$ & $43.04 \mathrm{~b}$ & $45.40 \mathrm{a}$ & $41.73 \mathrm{c}$ & \\
\hline
\end{tabular}

*Treatments followed by the same letter do not differ significantly $(\mathrm{p}<0.5)$ Duncan test; ${ }^{* *}$ Sampling followed by the same letter do not differ significantly $(\mathrm{p}<0.5)$ Duncan test.
Table 7. Effect of different treatments of $\mathrm{Cr}$ on chlorophyll content of four barley varieties.

\begin{tabular}{|c|c|c|c|c|}
\hline Variety & Treatment & SPAD values & SPAD values & Mean $^{*}$ \\
\hline & $\mathrm{mM}$ & $S 1$ & S2 & \\
\hline \multirow[t]{5}{*}{ CB502 } & 0 & 45.32 & 45.32 & $45.32 \mathrm{~b}$ \\
\hline & 1 & 55.82 & 55.42 & $55.61 \mathrm{a}$ \\
\hline & 2 & 51.90 & 28.37 & $40.13 \mathrm{c}$ \\
\hline & 3 & 21.58 & 10.92 & $16.25 \mathrm{~d}$ \\
\hline & Mean $^{* *}$ & $43.65 \mathrm{a}$ & $35.06 \mathrm{~b}$ & \\
\hline \multirow[t]{5}{*}{ Pedrezuela } & 0 & 44.32 & 40.85 & $42.58 \mathrm{a}$ \\
\hline & 1 & 42.20 & 46.47 & $44.33 \mathrm{a}$ \\
\hline & 2 & 46.45 & 13.08 & $29.76 \mathrm{~b}$ \\
\hline & 3 & 25.62 & 7.94 & $16.78 \mathrm{c}$ \\
\hline & Mean $^{* *}$ & $39.64 \mathrm{a}$ & $27.08 \mathrm{~b}$ & \\
\hline \multirow[t]{5}{*}{ Reinette } & 0 & 46.70 & 45.31 & $46.10 \mathrm{a}$ \\
\hline & 1 & 44.58 & 49.63 & $47.11 \mathrm{a}$ \\
\hline & 2 & 46.37 & 23.44 & $34.90 \mathrm{~b}$ \\
\hline & 3 & 32.23 & 9.78 & $21.01 \mathrm{c}$ \\
\hline & Mean $^{* *}$ & $42.47 \mathrm{a}$ & $32.04 \mathrm{~b}$ & \\
\hline \multirow[t]{5}{*}{ Plaisant } & 0 & 45.64 & 42.68 & $44.16 \mathrm{a}$ \\
\hline & 1 & 46.03 & 40.20 & $48.12 \mathrm{a}$ \\
\hline & 2 & 46.32 & 39.26 & $42.79 \mathrm{~b}$ \\
\hline & 3 & 19.78 & 9.78 & $14.78 \mathrm{c}$ \\
\hline & Mean $^{* *}$ & $39.44 \mathrm{a}$ & $32.98 \mathrm{~b}$ & \\
\hline
\end{tabular}

${ }^{*}$ Treatments followed by the same letter do not differ significantly $(\mathrm{p}<0.5)$ Duncan test; ${ }^{* *}$ Sampling followed by the same letter do not differ significantly $(\mathrm{p}<0.5)$ Duncan test.

tent obtained in the second sampling period were significantly lower than the values measured during the first period for all varieties studied. In contrast, when the $\mathrm{Cr}$ concentration increased, the chlorophyll content was significantly lower than in the control plants in the four varieties studied.

It was evident that the mean values for the genotypes followed the same trend for the $\mathrm{Zn}$ and $\mathrm{Cd}$ treatments, although differences between the genotypes were smaller. The CB502 variety demonstrated the highest chlorophyll content (39.33), followed by Reinette (37.28), Plaisant (37.46), and Pedrezuela (33.36). The differences were significant only between the CB502 and Pedrezuela genotypes.

\subsection{Chlorophyll Fluorescence}

In plants treated with different concentrations of $\mathrm{Zn}$ (Table 8), chlorophyll fluorescence was similar across all treatments. Between the sampling periods, the most important differences were between the first and final sampling period, except for the Plaisant variety plants, where no significant differences were recorded at any of the sampling periods. The varieties with the highest mean 
Table 8. Effect of different treatments of Zn on chlorophyll fluorescence of four barley varieties.

\begin{tabular}{|c|c|c|c|c|c|}
\hline Variety & Treatment & & $\mathrm{Fv} / \mathrm{Fm}$ & & Mean \\
\hline & $\mathrm{mM}$ & $S 1$ & $S 2$ & S3 & \\
\hline \multirow[t]{5}{*}{ CB502 } & 0 & 0.847 & 0.832 & 0.821 & $0.833 \mathrm{a}$ \\
\hline & 50 & 0.851 & 0.852 & 0.817 & $0.840 \mathrm{a}$ \\
\hline & 150 & 0.849 & 0.836 & 0.832 & $0.839 \mathrm{a}$ \\
\hline & 250 & 0.851 & 0.850 & 0.821 & $0.841 \mathrm{a}$ \\
\hline & Mean $^{* *}$ & $0.849 \mathrm{a}$ & $0.842 \mathrm{a}$ & $0.823 \mathrm{~b}$ & \\
\hline \multirow[t]{5}{*}{ Pedrezuela } & 0 & 0.838 & 0.841 & 0.540 & $0.740 \mathrm{~b}$ \\
\hline & 50 & 0.849 & 0.835 & 0.584 & $0.756 \mathrm{ab}$ \\
\hline & 150 & 0.843 & 0.834 & 0.650 & $0.775 \mathrm{a}$ \\
\hline & 250 & 0.845 & 0.838 & 0.653 & $0.779 \mathrm{a}$ \\
\hline & Mean $^{* *}$ & $0.844 \mathrm{a}$ & $0.837 \mathrm{a}$ & $0.607 \mathrm{~b}$ & \\
\hline \multirow[t]{5}{*}{ Reinette } & 0 & 0.849 & 0.826 & 0.825 & $0.833 \mathrm{a}$ \\
\hline & 50 & 0.849 & 0.836 & 0.838 & $0.841 \mathrm{a}$ \\
\hline & 150 & 0.853 & 0.833 & 0.831 & $0.839 \mathrm{a}$ \\
\hline & 250 & 0.852 & 0.838 & 0.828 & $0.839 \mathrm{a}$ \\
\hline & Mean $^{* *}$ & $0.850 \mathrm{a}$ & $0.833 \mathrm{~b}$ & $0.830 \mathrm{~b}$ & \\
\hline \multirow[t]{5}{*}{ Plaisant } & 0 & 0.847 & 0.835 & 0.831 & $0.838 \mathrm{a}$ \\
\hline & 50 & 0.849 & 0.830 & 0.833 & $0.837 \mathrm{a}$ \\
\hline & 150 & 0.845 & 0.833 & 0.826 & $0.835 \mathrm{a}$ \\
\hline & 250 & 0.844 & 0.837 & 0.836 & $0.839 \mathrm{a}$ \\
\hline & Mean $^{* *}$ & $0.846 \mathrm{a}$ & $0.834 \mathrm{a}$ & $0.831 \mathrm{a}$ & \\
\hline
\end{tabular}

*Treatments followed by the same letter do not differ significantly $(\mathrm{p}<0.5)$ Duncan test; ${ }^{* *}$ Sampling followed by the same letter do not differ significantly $(\mathrm{p}<0.5)$ Duncan test.

Fv/Fm values were CB502 and Reinette (0.838), followed by Plaisant $(0.837)$ and Pedrezuela $(0.763)$. There were no differences recorded in chlorophyll fluorescence among the different $\mathrm{Zn}$ concentrations tested. The Fv/Fm values were lower during the third sampling period, except for in the Plaisant variety plants, where no differences between periods appeared. The CB502 and Reinette varieties had the highest mean Fv/Fm values (0.838), followed by Plaisant (0.836) and Pedrezuela (0.763), which had significantly lower values.

In $\mathrm{Cd}$ treatments (Table 9), the $\mathrm{Fv} / \mathrm{Fm}$ values were similar between the control plants and those treated with the lowest metal concentrations, and these values were significantly lower for plants treated with the highest metal concentration for all genotypes tested. The only exceptions were in CB502 variety plants, where values for
Table 9. Effect of different treatments of Cd on chlorophyll fluorescence of four barley varieties.

\begin{tabular}{|c|c|c|c|c|c|}
\hline Variety & Treatment & & $\mathrm{Fv} / \mathrm{Fm}$ & & Mean $^{*}$ \\
\hline & $\mathrm{mM}$ & $S 1$ & $S 2$ & S3 & \\
\hline \multirow[t]{5}{*}{ CB502 } & 0 & 0.847 & 0.832 & 0.821 & $0.833 \mathrm{a}$ \\
\hline & 10 & 0.852 & 0.849 & 0.829 & $0.843 \mathrm{a}$ \\
\hline & 20 & 0.843 & 0.853 & 0.829 & $0.841 \mathrm{a}$ \\
\hline & 40 & 0.850 & 0.852 & 0.833 & $0.844 \mathrm{a}$ \\
\hline & Mean $^{* *}$ & $0.848 \mathrm{a}$ & $0.846 \mathrm{a}$ & $0.827 \mathrm{~b}$ & \\
\hline \multirow[t]{5}{*}{ Pedrezuela } & 0 & 0.838 & 0.841 & 0.640 & $0.773 \mathrm{a}$ \\
\hline & 10 & 0.840 & 0.831 & 0.694 & $0.788 \mathrm{a}$ \\
\hline & 20 & 0.845 & 0.822 & 0.645 & $0.770 \mathrm{a}$ \\
\hline & 40 & 0.838 & 0.838 & 0.586 & $0.754 \mathrm{~b}$ \\
\hline & Mean $^{* *}$ & $0.840 \mathrm{a}$ & $0.832 \mathrm{a}$ & $0.616 \mathrm{~b}$ & \\
\hline \multirow[t]{5}{*}{ Reinette } & 0 & 0.849 & 0.826 & 0.825 & $0.833 \mathrm{a}$ \\
\hline & 10 & 0.851 & 0.834 & 0.835 & $0.839 \mathrm{a}$ \\
\hline & 20 & 0.852 & 0.831 & 0.832 & $0.838 \mathrm{a}$ \\
\hline & 40 & 0.838 & 0.811 & 0.742 & $0.796 \mathrm{~b}$ \\
\hline & Mean $^{* *}$ & $0.847 \mathrm{a}$ & $0.825 \mathrm{~b}$ & $0.808 \mathrm{~b}$ & \\
\hline \multirow[t]{5}{*}{ Plaisant } & 0 & 0.847 & 0.835 & 0.831 & $0.837 \mathrm{a}$ \\
\hline & 10 & 0.842 & 0.840 & 0.840 & $0.840 \mathrm{a}$ \\
\hline & 20 & 0.842 & 0.845 & 0.831 & $0.842 \mathrm{a}$ \\
\hline & 40 & 0.841 & 0.839 & 0.767 & $0.815 \mathrm{~b}$ \\
\hline & Mean $^{* *}$ & $0.843 \mathrm{a}$ & $0.839 \mathrm{a}$ & $0.817 \mathrm{~b}$ & \\
\hline
\end{tabular}

${ }^{*}$ Treatments followed by the same letter do not differ significantly $(\mathrm{p}<0.5)$ Duncan test; ${ }^{* *}$ Sampling followed by the same letter do not differ significantly $(\mathrm{p}<0.5)$ Duncan test.

the high concentration treatments did not differ from the other three treatments. Across the sampling periods, the most important differences were observed between the first and the third periods. The varieties with the highest mean Fv/Fm values were CB502, Reinette, and Plaisant $(0.840,0.827$, and 0.834 , respectively). Pedrezuela displayed the lowest value $(0.771)$. The Fv/Fm values in plants treated with the highest $\mathrm{Cd}$ concentrations were significantly lower relative to the other treatments, except for the CB502 variety plants, in which it did not differ from the other treatments. The last sampling period recorded significantly lower values for the four varieties studied. CB501, Plaisant, and Reinette displayed the highest mean genotype values $(0.840,0.834$, and 0.827 , respectively), and Pedrezuela had the lowest value (0.771). 
As occurred with the chlorophyll content, the fluorescence also differed more in plants treated with different concentrations of $\mathrm{Cr}$ (Table 10). In the four varieties studied, the $\mathrm{Fv} / \mathrm{Fm}$ values corresponding to the highest metal concentration were significantly lower than those in the control plants. The second sampling period also had lower values than did the first period for the four genotypes. The differences between the varieties were small, with mean values of $0.806,0.804,0.793$, and 0.779 for CB502, Reinette, Plaisant, and Pedrezuela, respectively. This might be due to the more toxic effects of $\mathrm{Cr}$ in plants, which highly affected the growth and physiology of the plants treated with this metal.

The correlations between the SPAD values and FV/Fm values were high in the three sampling periods $(r=0.79$, $r=0.89$, and $r=0.77$ for the first, second, and third periods, respectively; $\mathrm{p}<0.001)$. The correlations between the height and SPAD values $(r=0.72 ; p<0.001)$, height and $\mathrm{Fv} / \mathrm{Fm}(\mathrm{r}=0.75 ; \mathrm{p}<0.001)$, dry weight and SPAD values $(r=67 ; \mathrm{p}<0.001)$, and fluorescence and dry weight values $(r=0.66 ; p<0.001)$ were also significant.

Table 10. Effect of different treatments of $\mathrm{Cr}$ on chlorophyll fluorescence of four barley varieties.

\begin{tabular}{|c|c|c|c|c|}
\hline \multirow[t]{2}{*}{ Variety } & \multirow{2}{*}{$\begin{array}{c}\text { Treatment } \\
\mathrm{mM}\end{array}$} & \multicolumn{2}{|c|}{$\mathrm{Fv} / \mathrm{Fm}$} & \multirow[t]{2}{*}{ Mean $^{*}$} \\
\hline & & $S 1$ & S2 & \\
\hline \multirow[t]{5}{*}{ CB502 } & 0 & 0.847 & 0.832 & $0.839 \mathrm{a}$ \\
\hline & 1 & 0.852 & 0.845 & $0.848 \mathrm{a}$ \\
\hline & 2 & 0.855 & 0.755 & $0.804 \mathrm{~b}$ \\
\hline & 3 & 0.743 & 0.720 & $0.731 \mathrm{c}$ \\
\hline & Mean $^{* *}$ & $0.824 \mathrm{a}$ & $0.787 \mathrm{~b}$ & \\
\hline \multirow[t]{5}{*}{ Pedrezuela } & 0 & 0.838 & 0.841 & $0.839 \mathrm{a}$ \\
\hline & 1 & 0.838 & 0.842 & $0.840 \mathrm{a}$ \\
\hline & 2 & 0.830 & 0.624 & $0.727 \mathrm{~b}$ \\
\hline & 3 & 0.728 & 0.689 & $0.708 \mathrm{c}$ \\
\hline & Mean $^{* *}$ & $0.808 \mathrm{a}$ & $0.748 \mathrm{~b}$ & \\
\hline \multirow[t]{5}{*}{ Reinette } & 0 & 0.849 & 0.826 & $0.837 \mathrm{a}$ \\
\hline & 1 & 0.850 & 0.805 & $0.827 \mathrm{a}$ \\
\hline & 2 & 0.836 & 0.754 & $0.795 \mathrm{~b}$ \\
\hline & 3 & 0.803 & 0.709 & $0.756 \mathrm{c}$ \\
\hline & Mean $^{* *}$ & $0.834 \mathrm{a}$ & $0.773 \mathrm{~b}$ & \\
\hline \multirow[t]{5}{*}{ Plaisant } & 0 & 0.847 & 0.835 & $0.841 \mathrm{a}$ \\
\hline & 1 & 0.838 & 0.849 & $0.843 \mathrm{a}$ \\
\hline & 2 & 0.829 & 0.747 & $0.788 \mathrm{~b}$ \\
\hline & 3 & 0.792 & 0.610 & $0.701 \mathrm{c}$ \\
\hline & Mean $^{* *}$ & $0.826 \mathrm{a}$ & $0.760 \mathrm{~b}$ & \\
\hline
\end{tabular}

*Treatments followed by the same letter do not differ significantly $(\mathrm{p}<0.5)$; Duncan test; ${ }^{* *}$ Sampling followed by the same letter do not differ significantly $(\mathrm{p}<0.5)$ Duncan test.

\section{Discussion}

In higher plants, growth inhibition and reduction in biomass production are considered to be responses to heavy metal toxicity; therefore, height and dry weight are used as indicators of toxicity [22]. The results obtained in this study indicate that the barley varieties studied were more sensitive to $\mathrm{Cr}$ treatments than to $\mathrm{Zn}$ or $\mathrm{Cd}$ treatments (Figure 1). Treatment with $\mathrm{Zn}$ did not negatively affect plant growth in the CB502 and Pedrezuela varieties, including at the highest concentration levels. In the $\mathrm{Cd}$ treatments, growth was somewhat reduced (i.e., $4 \%$ for CB502 and 5\% for Pedrezuela) when plants were treated with the highest concentration levels. For the Reinette and Plaisant varieties, the plants treated with the highest concentrations of $\mathrm{Zn}$ grew $4 \%$ less than control plants, and those treated with the higher concentration of $\mathrm{Cd}$ grew $8 \%$ and $6 \%$ less than control plants. The low and intermediate concentrations of $\mathrm{Zn}$ and $\mathrm{Cd}$ favored growth and increased the dry weight of the shoots and roots in all varieties of barley studied. Other studies have also demonstrated that plant growth in some species can be stimulated by high concentrations of $\mathrm{Zn}$ and other metals $[23,24]$. One possible explanation is that these species may have higher requirements of $\mathrm{Zn}$ and $\mathrm{Cd}$ than other plant types. At the lowest $\mathrm{Cr}$ concentrations, growth was reduced relative to the control plants, and at the highest $\mathrm{Cr}$ concentrations, plant growth stopped at the flag leaf stage (Figure 1). The toxic effect of $\mathrm{Cr}$ on growth and biomass reduction has been previously demonstrated in rice [25], in which tolerant varieties were identified, and in Lolium [26], in which the physiological parameters were also affected by $\mathrm{Cr}$ presence.

The dry weights were reduced in plants treated with $\mathrm{Cr}$ compared to plants treated with $\mathrm{Zn}$ or Cd (Figure 2), which indicates the lower tolerance to $\mathrm{Cr}$ in the studied varieties. Differences were also observed between varieties, with CB502 having the highest weights, followed by Reinette, Plaisant, and Pedrezuela. Generally, the stress produced by metals reduces plant growth due to a reduction in the chlorophyll content and the consequent inhibition of photosynthesis [22,27-29]. This fact is consistent with our results because the mean chlorophyll content and fluorescence values were higher for CB502 and Reinette, followed by Plaisant and Pedrezuela, for all $\mathrm{Zn}, \mathrm{Cd}$, and $\mathrm{Cr}$ treatments (Tables 5-10). The negative effect of $\mathrm{Cd}$ and $\mathrm{Cr}$ on photosynthesis may be due to limitations in mesophyll cells due to a reduction in both light efficiency and the transport rate of electrons implicated in PSII, as was demonstrated by Vasilev $[12,30]$ in barley and by Vernay [26] in Lolium. The results for $\mathrm{Fv} / \mathrm{Fm}$ at the highest metal concentration levels, which were significantly lower for all varieties, are consistent with this argument. 
The amount of accumulated metal in the aerial parts and the roots increased significantly with increasing metal concentrations in the soil (Tables 2-4). Metal accumulated preferentially in the root, and a significant relationship has been observed between the metal concentration applied to the soil and the concentration measured in the roots and stems. This suggests that the root was the first place to accumulate metal and that small amounts of metal were translocated to the aerial part of the plant. The greatest metal accumulation in roots and aerial parts has been confirmed in species as different as Hordeum vulgare [31], Triticum turgidum [19], Vicia faba [20], Nicotiana tabacum [23], Eruca sativa [32], and Prunus dulcis [28]. Following treatment with $\mathrm{Zn}$ or $\mathrm{Cd}$, the genotypes CB502, Plaisant, and Pedrezuela accumulated approximately twice the amount of metal in their roots relative to their aerial parts; however, Reinette accumulated 16 -fold more $\mathrm{Zn}$ in the roots than in the aerial parts and 34-fold more $\mathrm{Cd}$. These data indicate that the first three genotypes have a mechanism of tolerance to $\mathrm{Zn}$ that allows them to accumulate metal in their tissues without affecting plant survival. Reinette seems to tolerate large amounts of $\mathrm{Zn}$ and $\mathrm{Cd}$, hindering the translocation of these metals from the root to the aerial parts. In the $\mathrm{Cr}$ treatments, slightly more than double the amount of metal accumulated in the root relative to the aerial parts in all genotypes except in Reinette, where twice the amount of metal accumulated in the roots relative to the aerial parts, which indicates the existence of more barriers to metal transport towards the shoot in this variety.

In summary, the traits studied in barley displayed variability, and this suggests the existence of two apparent groups. CB502 and Reinette were most tolerant to the concentrations of metals used in our trials because their growth was least affected by metals and their chlorophyll content and fluorescence values were higher relative to the Pedrezuela and Plaisant varieties. The Plaisant variety plants accumulated greater amounts of $\mathrm{Zn}$, Reinette accumulated greater amounts of $\mathrm{Cd}$, and CB502 accumulated greater amounts of $\mathrm{Cr}$. This is of great interest when selecting a certain variety for phytoextraction in contaminated soils because different plants will vary in their tolerance and extraction capacity based on the type of metal present in the soil.

\section{REFERENCES}

[1] A. J. M. Baker, S. P. McGrath, R. D. Reeves and J. A. C. Smith, "Metal Hyperaccumulator Plants: A Review of the Ecology and Physiology of a Biological Resource for Phytoremediation of Metal-Populled Soils," In: N. Terry and G. Bañuelos, Ed., Phytoremediation of Contaminated Soil and Water, CRP Press LLC, Boca Raton, 2000, pp. 85-107.
[2] S. P. McGrath, F. J. Zhao and E. Lombi, "Plant and Rhizosphere Processes Involved in Phytoremediation of Metal-Contaminated Soils," Plant and Soil, Vol. 232, No. 1-2, 2001, pp. 207-214. doi:10.1023/A:1010358708525

[3] S. P. McGrath, F. J. Zhao and E. Lombi, "Phytoremediation of Metals, Metalloids, and Radionucleides," Advances in Agronomy, Vol. 75, 2002, pp. 1-56. doi:10.1016/S0065-2113(02)75002-5

[4] R. L. Chaney, "Plant Uptake of Inorganic Waste Constituents," In: J. F. Parr, P. B. Marsch and J. S. Kla, Eds., Land Treatment of Inorganic Wastes, Noyes Data, Park Ridge, 1983, pp. 50-76.

[5] D. E. Salt, M. Blaylock, N. P. B. A. Kumar, V. Dushenkov, B. D. Ensley, I. Chet and I. Raskin, "Phytoremediation: A Novel Strategy for the Removal of Toxic Metals from the Environment Using Plants," BioTechnology, Vol. 13, No. 5, 1995, pp. 468-474. doi:10.1038/nbt0595-468

[6] S. D. Cunningham and D. W. Ow, "Promises and Prospects of Phytoremediation," Plant Physiology, Vol. 110, No. 3, 1996, pp. 715-719.

[7] D. E. Salt, R. D. Smith and I. Raskin, "Phytoremediation," Annual Review of Plant Physiology and Plant Molecular Biology, Vol. 49, No. 1, 1998, pp. 643-668. doi:10.1146/annurev.arplant.49.1.643

[8] M. A. Soriano and E. Federes, "Use of Crops for in Situ Phytoremediation of Polluted Soils Following a Toxic Flood from a Mine Spill," Plant and Soil, Vol. 256, No. 2, 2003, pp. 253-264. doi:10.1023/A:1026155423727

[9] C. W. A. Nascimento and B. Xing, "Phytoextraction: A Review on Enhanced Metal Availability and Plant Accumulation," Scientia Agricola, Vol. 63, No. 3, 2006, pp. 299-311. doi:10.1590/S0103-90162006000300014

[10] J. M. Clark, W. A. Norvell, F. R. Clark and W. T. Buckley, "Concentration of Cadmium and Other Elements in the Grain of Near-Isogenic Durum Lines," Canadian Journal of Animal Science, Vol. 82, No. 1, 2002, pp. 27 33.

[11] D. Ueno, E. Koyama, N. Yamaji and J. F. Ma, "Physiological, Genetic, and Molecular Characterization of a High-Cd-Accumulating Rice Cultivar, Jarjan," Journal of Experimental Botany, Vol. 62, No. 7, 2011, pp. 22652272. doi:10.1093/jxb/erq383

[12] A. Vassilev, J. Vangronsveld and I. Yordanov, "Cadmium Phytoextraction: Present State, Biological Backgrounds and Research Needs," Bulgarian Journal of Plant Physiology, Vol. 28, No. 3-4, 2002, pp. 68-95.

[13] X. Zhang, G. Zhang, L. Guo, H. Wang, D. Zeng, G. Dong, O. Qian and D. Xue, "Identification of Quantitative Trait Loci for Cd and Zn Concentrations of Brown Rice Grown in Cd-Polluted Soils," Euphytica, Vol. 180, No. 2, 2011, pp. 173-179. doi:10.1007/s10681-011-0346-9

[14] M. M. Lasat, "Phytoextraction of Metals from Contaminated Soil: A Review of Plant/Soil/Metal Interaction and Assessment of Pertinent Agronomic Issues," Journal of Hazardous Substance Research, Vol. 2, No. 5, 2000, pp. $1-25$.

[15] S. Kärenlampi, H. Schat, J. Vangronsveld, J. A. C. Verk- 
leij, D. van der Lelie, M. Mergeay and A. I. Tervahauta, "Genetic Engineering in the Improvement of Plants for Phytoremediation of Metal Polluted Soils," Environmental Pollution, Vol. 107, 2000, pp. 225-231. doi:10.1016/S0269-7491(99)00141-4

[16] M. R. Macnair, V. Bert, S. B. Huitson, P. Saumitou-Laprade and D. Petit, "Zinc Tolerance and Hyperaccumulation Are Genetically Independent Characters," Proceedings of the Royal Society B, Vol. 266, No. 1434, 1999, pp. 2175-2179. doi:10.1098/rspb.1999.0905

[17] N. Roosens, N. Verbruggen, P. Meerts, P. Ximénez-Embún and J. A. C. Smith, "Natural Variation in Cadmium Tolerance and Its Relationship to Metal Hyperaccumulation for Seven Populations of Thlaspi caerulescens from Western Europe," Plant, Cell and Environment, Vol. 26, No. 10, 2003, pp. 1657-1672. doi:10.1046/j.1365-3040.2003.01084.x

[18] M. J. McLaughlin, D. R. Parker and J. M. Clarke, "Metals and Micronutrients-Food Safety Issues," Field Crops Research, Vol. 60, No. 1, 1999, pp. 143-163. doi:10.1016/S0378-4290(98)00137-3

[19] B. A. Adeniji, M. T. Budimir-Hussey and S. M. Macfie, "Production of Organic Acids and Adsorption of $\mathrm{Cd}$ on Roots of Durum Whea (Triticum turgidum L. var. Durum),"Acta Physiologiae Plantarum, Vol. 32, 2010, pp. 1063-1072. doi:10.1007/s11738-010-0498-6

[20] R. Cabala, L. Slováková, M. El Zohri and H. Frank, “Accumulation and Translocation of $\mathrm{Cd}$ Metal and the CdInduced Production of Glutathione and Phytochelatins in Vicia faba L," Acta Physiologiae Plantarum, Vol. 33, No. 4, 2011, pp. 1239-1248. doi:10.1007/s11738-010-0653-0

[21] J. C. Zadoks, T. T. Chang and C. F. Kozank, "A Decimal Code for the Growth Stages of Cereals," Weed Research, Vol. 14, No. 6, 1974, pp. 415-421. doi:10.1111/j.1365-3180.1974.tb01084.x

[22] D. Ci, D. Jiang, B. Wollenweber, T. Dai, Q. Jing and W. Cao, "Cadmium Stress in Wheat Seedlings: Growth, Cadmium Accumulation and Photosynthesis," Acta Phisiologiae Plantarum, Vol. 32, No. 2, 2010, pp. 365-373. doi:10.1007/s11738-009-0414-0

[23] L. L. Martins, M. P. Mourato, A. I. Cardoso, A. P. Pinto, A. M. Mota, M. L. S. Goncalves and A. de Varennes, "Oxidative Stress Induced by Cadmium in Nicotiana tabacum L.: Effects on Growth Parameters, Oxidative Damage and Antioxidant Responses in Different Plant Parts," Acta Physiologiae Plantarum, Vol. 33, 2011, pp. 1375-1383. doi:10.1007/s11738-010-0671-y

[24] Y. Yang, Ch. Sun, Y. Yao, Y. Zhang and V. Achal,
"Growth and Physiological Responses of Grape (Vitis vinifera "Combier") to Excess Zinc," Acta Physiologiae Plantarum, Vol. 33, No. 4, 2011, pp. 1483-1491. doi:10.1007/s11738-010-0687-3

[25] B. Qiu, W. Zhou, D. Xue, F. Zeng, S. Ali and G. Zhang, "Identification of Cr-Tolerance Lines in a Rice (Oryza sativa L.) DH Population," Euphytica, Vol. 174, No. 2, 2010, pp. 199-207. doi:10.1007/s10681-009-0115-1

[26] P. Vernay, C. Gauthier-Moussard and A. Hitmi, "Interaction of Bioaccumulation of Heavy Metal Chromium with Water Relation, Mineral Nutrition and Photosynthesis in Developed Leaves of Lolium perenne L," Chemosphere, Vol. 68, No. 8, 2007, pp. 1563-1575. doi:10.1016/j.chemosphere.2007.02.052

[27] L. M. Sandalio, H. C. Dalurzo, M. Gómez, M. C. Romero-Puertas and L. A. del Río, "Cadmium-Induced Changes in the Growth and Oxidative Metabolism of Pea Plants," Journal of Experimental Botany, Vol. 52, 2010, pp. 2115-2126.

[28] E. Nada, B. A. Ferjani, R. Ali, B. R. Bechir, M. Imed and B. Makki, "Cadmium-Induced Growth Inhibition and Alteration of Biochemical Parameters in Almond Seedlings Grown in Solution Culture," Acta Physiologiae Planttarum, Vol. 29, 2007, pp. 57-62. doi:10.1007/s11738-006-0009-y

[29] R. W. dos Santos, E. C. Schmidt, R. Martins, A. Latini, M. Maraschin, P. A. Horta and Z. L. Bouzon, "Effects of Cadmium on Growth, Photosynthetic Pigments, Photosynthetic Performance, Biochemical Parameters and Structure of Chloroplasts in the Agarophyte Gracilaria domingensis (Rhodophyta, Gracilariales)," American Journal of Plant Sciences, Vol. 3, No. 8, 2012, pp. 1077-1084. doi:10.4236/ajps.2012.38129

[30] A. Vassilev, I. Yordanov and T. Tsonev, "Effects of $\mathrm{Cd}^{2+}$ on the Physiological State and Photosynthetic Activity of Young Barley Plants," Photosynthetica, Vol. 34, No. 2, 1997, pp. 293-302. doi:10.1023/A:1006805010560

[31] A. González, V. Chumillas and M. C. Lobo, "Effect of Zn, $\mathrm{Cd}$ and $\mathrm{Cr}$ on Growth, Water Status and Chlorophyll Content of Barley Plants (H. vulgare L.)," Agricultural Sciences, Vol. 3, No. 4, 2012, pp. 572-581. doi:10.4236/as.2012.34069

[32] Y. Ozdener and B. K. Aydin, "The Effect of Zinc on the Growth and Physiological and Biochemical Parameters in Seedlings of Eruca sativa (L.) (Rocket)," Acta Physiologiae Plantarum, Vol. 32, No. 3, 2010, pp. 469-476. doi:10.1007/s11738-009-0423-Z 